\title{
PROTEIN DETERMINATION THROUGH BRADFORD'S METHOD OF NEPALESE MUSHROOM
}

\author{
Nina Pandey* and Usha Budhathoki** \\ *Department of Botany, Patan Multiple Campus, Tribhuvan University, Lalitpur, Nepal. \\ **Central Department of Botany, Tribhuvan University, Kirtipur, Kathmandu, Nepal.
}

\begin{abstract}
The Wild edible mushrooms are one of the most important non timber forest products. Due to its vigorous growth in the rainy season, delicious taste and nutritional value the mycophagus group consume them. In this paper an attempt has been made to determine the protein of these 35 species through Bradford's method. Among them thirty three species of wild mushroom collected from different altitude $(200 \mathrm{~m}-4200 \mathrm{~m})$, phytogeographical habitat of central Nepal and two species Agaricus bisporous \& Pleurotus sajorkaju cultivated sample from Balambu farm. The highest amount of protein $1.576 \mathrm{mg} / \mathrm{ml}$ in Cantharellus subscibarius and least $0.131 \mathrm{mg} / \mathrm{ml}$ in Cordycep sinensis were found.
\end{abstract}

Key words: Wild mushroom; Protein; Bradford's method.

\section{INTRODUCTION}

Protein is the most critical component contributing to the nutritional value of food. The determination of crude protein was done by the procedure known as Micro Kjeldahl's process (Sawhney, Singh, 2000). However, this process is both time consuming and sample consuming (Young, 1963).

Bradford's Method (Bradford, 1976) is a rapid, simple and sensitive method for estimation of proteins in a sample extract. The color development is virtually complete in 2 minutes and the color is stable for about 1 hour. Unlike Lowry's method (Lowry et.al.,1951) metal ions such as $\mathrm{NH}_{4}^{+}, \mathrm{Na}^{+}, \mathrm{K}^{+}$, phenol and carbohydrate such as sucrose do not interfere in this assay. The procedure is based on interaction of a dye, Coosmassic Brillaint Blue with protein.

Wild edible mushrooms are one of the important minor forest products, which are locally traded in local market of the country. In Nepal the mushroom collection and consumption have been continuing since time immemorial by different ethnic groups. Due to the lack of scientific knowledge in ethnic groups, they only utilized few species that could be identified from their own traditional knowledge. Various mycophagus groups like Sherpa, Tamang, Gurung, Tharu, Danuwar, Chepang and Newar are directly concerned with the collection and consumption of mushrooms since long due to its delicious taste as well as vigorous growth during rainy season in appropriate habitat in the forest of the country. Due to their high content of vitamin, protein and mineral, mushrooms are considered as “Poor man's Protein”(Pandey 2004).

The Greeks and Romans described mushrooms as "Food for the Gods”, and were served only on celebrations. Reference to mushrooms is found in Vedas (Chaube, 1995; Adhikari, 2000, 2004). Mushrooms can be used for the food to solve the malnutrition problem (Manandhar, 2003). Mushrooms have good nutritional value particularly as a source of protein that can enrich human diets especially in some developing countries where animal protein may not be available and are expensive. The protein content of fresh mushroom is 3.7\% stated by Food Agriculture Organization's publication in 1978. The edible and medicinal mushrooms can be used on human welfare in the $21^{\text {st }}$ century (Chang, 1999).

Nowadays the marketing of wild mushroom is decreasing due to new policy of forest conservation applied by Nepal Government yet some delicious mushrooms were also supplied in the reputed hotels through different means. Wild edible mushrooms are also called "Rajashi Khana (Food for Royal Palace)" due to delicious taste (Pandey, 2004). More than twenty species of mushrooms have been cultivated commercially around the world (Manandhar, 1994).

\section{OBJECTIVES}

The main objective of this research is

- To collect and identify mushroom samples in the study area.

- To find out the amount of protein present in different species of mushrooms.

\section{MATERIALS AND METHODS}

The mushrooms needed for the research were collected from the Langtang, Kathmandu valley and adjoining area. Identification of different collected samples were done on

Author for Correspondence: Nina Pandey, Department of Botany, Patan Multiple Campus, Tribhuvan University, Lalitpur, Nepal. Email: ninapandey@yahoo.com. 


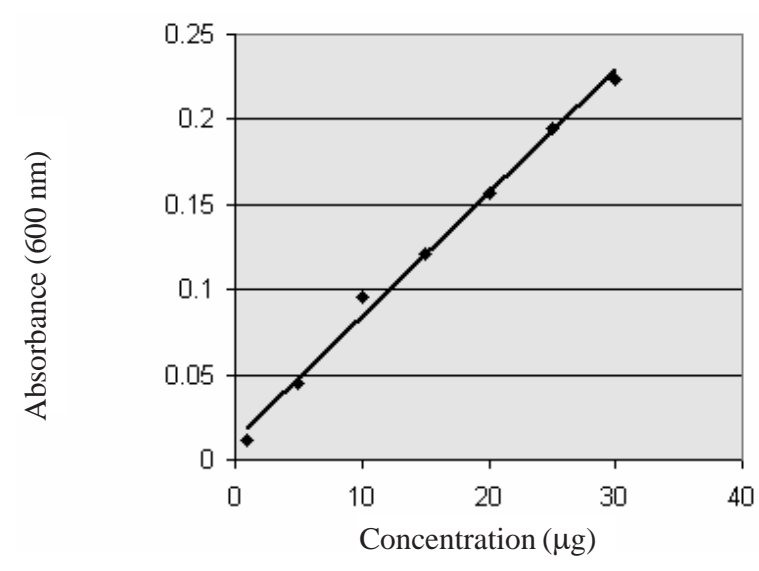

Figure 1: BSA Calibration curve for Bradford Method.

the basis of different important mushrooms characters and techniques such as habit and habitat, morphological structures, spore print color, microscopic observations, relevant monograph, recent literatures and books (Adhikari, 1990, 2000; Arora, 1986; Pandey, 2004; Pandey, 2006 a,b,c; Pacioni, 1981; Singer, 1986, Rea, 1922; Fries, 1838; Millor, 1984. Internet as well as cross checking with the voucher specimen. The proteins were determined by Bradford's method (Bradford, 1976).

An amount of $2 \mathrm{gm}$ of mushroom samples were cut into pieces with a scissor and grinded in mortar with $5 \mathrm{ml}$ of phosphate buffer ( $\mathrm{pH}$ 7.6) and was then transformed to the centrifuge tubes. The homogenate was centrifuged at $8000 \mathrm{rpm}$ for 20 minutes. The supernatant of different mushroom samples were put in separate tubes. The volume of all of the samples in tubes were then made equal by adding phosphate buffer solution and the extraction were stored in the refrigerator at $4^{0} \mathrm{C}$ for further analysis.

After extraction, 30 $\mu$ l of different mushroom samples were taken out in separate tubes and were mixed with $70 \mu \mathrm{l}$ of distilled water separately. In all of these separate sample tubes $2.9 \mathrm{ml}$ of Coosmassic Brillaint Blue solution was then added and mixed thoroughly. The Total volume now was $3 \mathrm{ml}$ in each tube. All these tubes were incubated for 5 minutes at room temperature and absorbance at 600(595) nm was recorded against the reagent blank. A standard curve of Absorbance $(600 \mathrm{~nm})$ versus Concentration $(\mu \mathrm{g})$ of protein was plotted as shown in Figure 1.

Protein content in the extracted samples was determined from the standard curve and the amount of protein in $\mathrm{mg} / \mathrm{ml}$ was calculated. The results were illustrated in the Table1.

\section{RESULTS}

The highest amount of protein was observed in Cantharellus subcibarius $1.567 \mathrm{mg} / \mathrm{ml}$ followed by Russula Virescens 1.427 $\mathrm{mg} / \mathrm{ml}$, Lactarius piperatus $1.38 \mathrm{mg} / \mathrm{ml}$ and least amount of protein was found in Cordycep sinemsis $0.131 \mathrm{mg} / \mathrm{ml}$. (Table 1)

Table 1

\begin{tabular}{|c|c|c|c|c|c|}
\hline Sample & Coll.No & Place of coll. & Abs(600nm) & Conc. in $30 \mu \mathrm{l}$ & protein $\mathrm{mg} / \mathrm{ml}$ \\
\hline Agaricus bisporous & Market & Baneshwor & 0.1 & 19.22222 & 0.509 \\
\hline Agaricus campestris & 24536 & Kirtipur & 0.18 & 23.38889 & 0.779 \\
\hline Amanita vaginata & 24609 & Matatirtha & 0.1 & 12.27778 & 0.27 \\
\hline Cantharellus cibarius & 24630 & Suryabinayak & 0.24 & 31.72222 & 1.057 \\
\hline Cantharellus subcibarius & 24606 & Matatirtha & 0.35 & 47 & 1.567 \\
\hline Clavaria rosea & 24584 & Sundarijal & 0.07 & 8.111111 & 0.27 \\
\hline Coprinus comatus & 21108 & Langtang & 0.11 & 13.66667 & 0.456 \\
\hline Cordycep sinensis & 23455 & Langtang & 0.04 & 3.944444 & 0.131 \\
\hline Coriolus hirsitus & 25645 & Matatirtha & 0.07 & 8.111111 & 0.27 \\
\hline Ganoderma tsugae & 23440 & Langtang & 0.08 & 9.5 & 0.316 \\
\hline Hypholoma capsonoid & 25653 & Langtang & 0.18 & 23.38889 & 0.779 \\
\hline Laccaria laccata & 25629 & Suryabinayak & 0.16 & 20.61111 & 0.687 \\
\hline Laccaria laccata & 24598 & Matatirtha & 0.19 & 24.77778 & 0.826 \\
\hline Laccaria laccata & 24526 & Godawari & 0.14 & 17.83333 & 0.594 \\
\hline Lactarius piperatus & 22158 & Suryabinayak & 0.31 & 41.44444 & 1.38 \\
\hline Lactarius volemus & 24570 & Tistung Palung & 0.09 & 10.88889 & 0.27 \\
\hline Laetiporous sulphureus & 24541 & Langtang & 0.16 & 20.61111 & 0.687 \\
\hline Marasmius maximus & 24572 & Tistung Palung & 0.09 & 8.111111 & 0.27 \\
\hline Morchella conica & 23461 & Langtang & 0.14 & 17.8333 & 0.594 \\
\hline Mycena Sp & 25651 & Langtang & 0.16 & 20.61111 & 0.687 \\
\hline Omphalotus olearis & 24576 & Baneshwor & 0.16 & 20.61111 & 0.687 \\
\hline Oudemensiella radicata & 24617 & Baneshwor & 0.14 & 17.8333 & 0.594 \\
\hline Pahelo chyau & 24573 & Baneshwor & 0.1 & 12.27778 & 0.409 \\
\hline Pleurotus sajorkaju & Market & Tistung Palung & 0.15 & 12.27778 & 0.64 \\
\hline Pleurotus Cornucopiae & 23469 & Matatirtha & 0.16 & 20.61111 & 0.687 \\
\hline
\end{tabular}


Abbreviations: $\mathrm{Sp}=$ Species, Conc $=$ Concentration, Coll $=$ Collection, No $=$ Number.

\section{Sample Versus Amount of protein in $\mathrm{mg} / \mathrm{ml}$ Charts:}

Sample Versus Amount of protein in $\mathbf{m g} / \mathrm{ml}$ Chart

Pleurotus sp

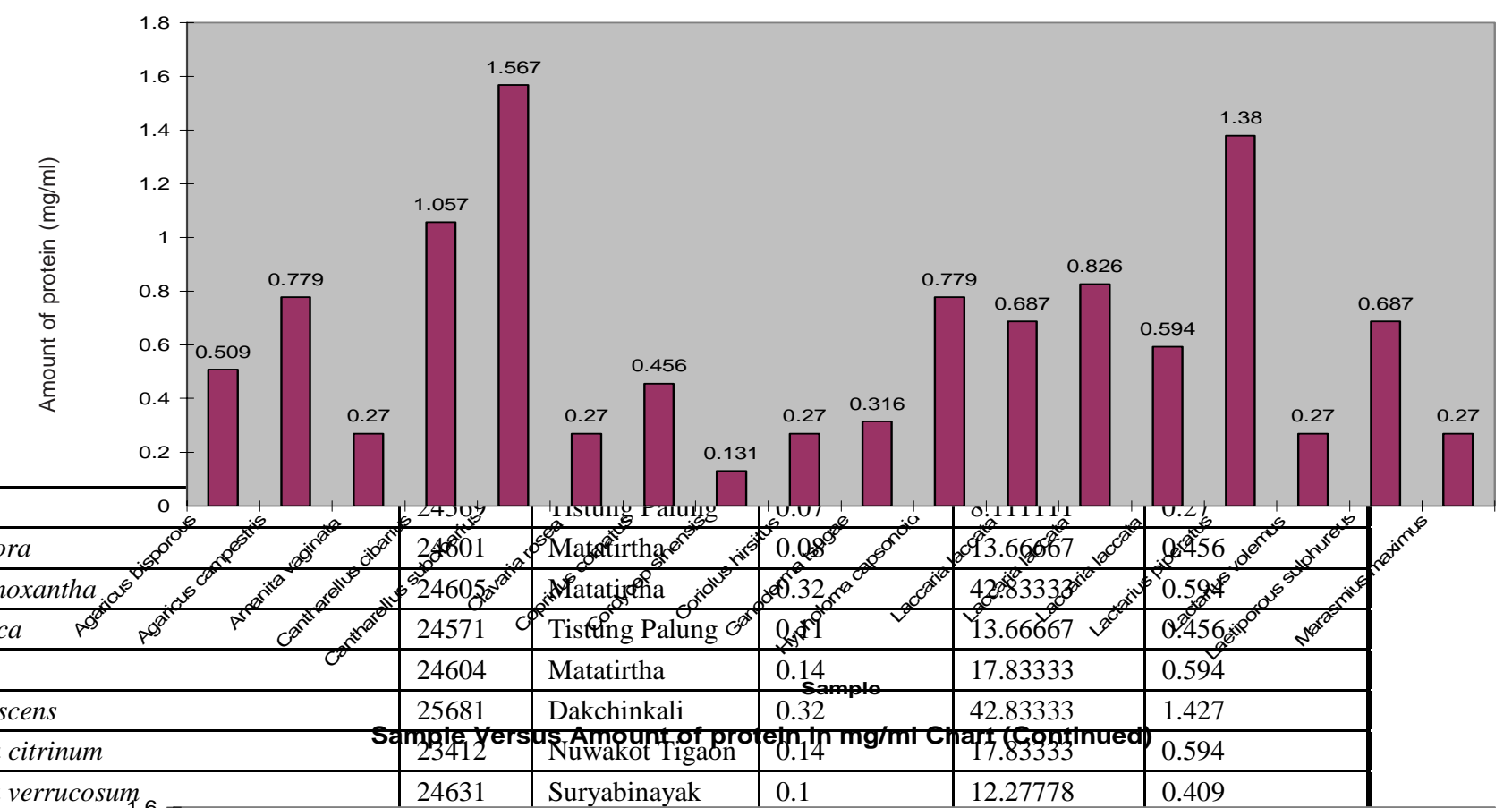

Russula aurora

Russula cyanoxantha $\sigma^{\circ}$

Russula delica

Russula sp

Russula virescens

Scleroderma citrinum

Scleroderma verrucosum

\begin{tabular}{ll}
\hline Thelephora fuscella \\
\hline Trametes versicolor \\
\hline
\end{tabular}

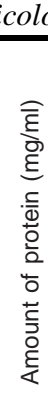

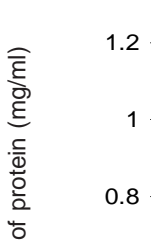

.

0.1

12.27778

0.409 


\section{DISCUSSION AND CONCLUSION}

Large amount of protein is found in mushrooms. Hence it is regarded as an ideal protein source for vegetarian as well as for old age people who are unable to chew meat. It was found that the amount of protein varies from species to species in the same genus as for example two different species of genus Cantharellus, i.e., Cantharellus cibarius contents $1.057 \mathrm{mg} /$ $\mathrm{ml}$ of protein while Cantharellus subcibarius contents 1.567 $\mathrm{mg} / \mathrm{ml}$ of protein. Similarly the three different species of the genus Pleurotus, four species of the genus Russula and two species of the genus Scleroderoma have different protein concentration as shown in the Table1.

In our research, wild edible mushrooms Laccaria laccata collected from three different places namely Godawari, Matatirtha and Suryabinayak were found to have 0.594, 0.862 and $0.687 \mathrm{mg} / \mathrm{ml}$ amount of protein. Clearly, it was seen that the amount of protein in $\mathrm{mg} / \mathrm{ml}$ is different even in the mushrooms of the same species collected at the three different places. Hence it was also concluded from the research that the amount of protein varied even in the same species according to phytographical condition.

\section{ACKNOWLEDGEMENT}

We are thankful to Dr. M.K. Adhikari, the chief, and V.Manandhar, Mycologist, Department of Plant Resources, National Herbarium and Plant Laboratories, Godavari as well as Prof. S.C. Singh, the mycologist, Research Center for Applied Science and Technology for their valuable suggestions. We would like to express our sincere gratitude to Prof. Dr. Pramod Kumar Jha, the Head of Department of Botany as well as Associate Prof. Dr. Surya Prasad Manandhar and Assistant Lecturer Mr. Yogan Khatri of Microbiology Department of Tribhuvan University for providing us with necessary available laboratory facilities.

\section{REFERENCES}

Adhikari, M.K. 2000. Mushrooms of Nepal. Edited by G.Durrieu, P.U. Printers, Battisputali, Kathmandu, Nepal. P. 236.

Adhikari, M.K. 1990. History of mycological explorations in Nepal. Cryptog.Mycol. 11(2): 111.

Adhikari, M.K. 2004. Nepalma Jangali Chyaharuko Sankalan ra byapar (Wild mushroom trade in Nepal). Prakit. 2(3): 27-31 (in Nepali).
Arora, D. 1986. Mushroom Demystified; comprensive guide to the fleshy fungi. Berkely ten speed Press. P. 959.

Bradford, M.M. 1976. Anal. Biochem. 72: 248-254.

Chang S.T. 1999. Global impact of edible and medicinal mushrooms on human welfare in the 21st century: nongreen revolution. International Journal of Medicinal Mushrooms. 1:1-8.

Chaube, H.S. 1995. Nutrational and Medicinal value of Mushroom. Mushroom production Technology; University of Agriculture and Technology, India. Pp.1-6.

F.A.O. 1978. F.A.O Production year Book. Vol. 32.

Fries, E. M. 1838 Epicrisis Systematis Mycologici. Upsala.

Lowry, O.H., Rosebrough, N. J., Farr, A. L. and Randall, R. J. 1951. J. Biol. Chem. 93: 265-275.

Manandhar, K.L. 1994. Mushroom cultivation in Nepal Second National Conference on Science \& Technology. Pp. 922-966.

Manandhar, K.L. 2003. Mushroom cultivation Technology for women's Income.Proceedings of International Conference on Women's Science \& Technology for Proverty Alleviation.

Miller, O.K. 1984. Mushrooms of north America. E. P. Dutton Publishing Company Inc., New York. P.368,

Pacioni. 1981. Guide to Mushrooms. Edited by Garry H. Lincoff, Published by Simon \& Schuster inc. New York, London. P. 511.

Pandey, N. 2004. Chemical Analysis of Mushroom of Kathmandu valley. Submitted to University Grant Commission.

Pandey, Nina and Budhathoki, Usha. 2006c. Mushrooms in the Langtang,Gosainthan, a sacred wetland in Nepal, Wetland studies series. 3: 62-68.

Pandey, Nina and Budhathoki,Usha. 2006b. Profiling of Major Proteins in Wild Nepalese Mushrooms by SDS Page. Plant Archives. 6(2): 465-469.

Pandey, Nina. 2006a. Preliminery Study on the Mushroom's Diversity of Langtang National Park- Submitted to Department of National Park and Wildlife Conservation.

Rea, C. 1922. British Basidiomycetaceae. Biblio. Mycol. 15. J. Cramer. P. 799.

Sawhney, S.K. and Singh, Randhir. 2000. Introductory Practical Biochemistry Edited by S.K. Sawhney, Randhir Singh Narosa Publishing House New Delhi. P. 452.

Singer, R. 1986. The Agaricales in modern taxonomy. Klotz. Scientific, Germany. P. 912.

Young, E.G. 1963. In Comprehensive Biochemistry. Vol. 7 (Florkin, M. and Stotz, E.H., eds.) Elsevier, Amsterdem. Pp. 1-55. 